\title{
GEOCHEMICAL SIGNATURES OF METATEXITE AND DIATEXITE MIGMATITE WITHIN GWARZO LOW GRADE METASEDIMENTS NW NIGERIA
}

\author{
Ahmed Abubakar Sarki 1, 2 Ahmad Isah Haruna 1 Nasir Abdullahi Maiauduga 3 \\ Department of Applied Geology, Faculty of Science, Abubakar Tafawa Balewa University \\ Bauchi 1 \\ Department of Geology, Faculty of Earth and Environmental Science, Bayero University Kano \\ 2 \\ Department of Geological Technology, School of Science Abubakar Tatari Ali Polytecnic, \\ Bauchi 3 \\ Email, :asarki.pg@atbu.edu.ng aasarki.geo@buk.edu.ng
}

\begin{abstract}
The study area shows a distinctive morphological and geochemical continuity from the early formed metasediments, to the metatexite (i.e. the banded orthogneiss and stromatic migmatite), to diatexite (i.e. nebulitic and nebulitic patch migmatite). The geochemistry indicates the decrease in $\mathrm{Fe} 2 \mathrm{O} 3, \mathrm{MgO}$, and $\mathrm{TiO} 2$ in the metatexite and diatexite with increasing silica, indicating feldspar ratio content rise. Also the modal mineralogy based on whole rock composition indicate the metasediment is rich in biotite and corondum, with small amount of quartz. The $\mathrm{FeO}+\mathrm{MgO}$ vs $\mathrm{K} 2 \mathrm{O}$ shows the compositional field and also correspond with mineralogical composition of the studied samples, with the metasediments rich in biotite and cordierite, which decreases as they are transformed to metatexite, with plagioclase and quartz replacing the earlier formed minerals and the nebulitic migmatite rich in K-feldspar.
\end{abstract}

Keywords:Biotite, Nebulite, Metatexite, Migmatite. 